\title{
RECONFIGURING STATE-MINORITY NEGOTIATIONS FOR BETTER OUTCOMES
}

\section{Sherrill Stroschein}

The governance of states that are home to several different identity groups can become a focus of struggle between those groups. Most states in the world contain a variety of ethnic and religious groups that produce identity-based majorities and minorities. In democracies, majority groups will have strong governance advantages over minorities, unless these advantages are mitigated by electoral systems accommodating minorities as well as minority rights protection schemes. ${ }^{1}$ Scholars and policymakers have considered which of these options might be best for resolving the day-to-day disagreements and agreements between majorities and minorities in democracies, without simply resorting to majority tyranny. These considerations tend to be framed as rights, or as institutions for minority protection.

Majorities and minorities will frequently disagree on policies relating to their different identities. The nature of such disputes tend to focus on matters such as language use and education, religious practice, the public display of group symbols, and group holidays and commemorations. In theory, policy, and law, some advocate approaching these questions as those of individual human rights. From this perspective, identity groups are simply a collection of individuals with individual rights. While minority practices regarding language use or religion might be infringed upon, these harms take place on an individual, rather than a collective basis. Thus, some theorists argue they must be addressed using remedies that are based in individual rights. ${ }^{2}$ In this individualist or egalitarian view, individual rights protections regarding language and culture should be sufficient to address these dilemmas. For strict egalitarians, based on these premises a just society does not require special attention to groups or group rights. ${ }^{3}$ Reflecting the predominance of this view, most minority rights treaties are based on individual rights.

This individualist position is disputed by a range of others who argue that in theory, law and policy individual rights are not sufficient to address these questions, because they are inherently group-based. This viewpoint is reflected in the communitarian and

\footnotetext{
${ }^{1}$ However, even proportional representation electoral systems (or ranked systems) cannot completely eliminate the fact that minorities will be outnumbered by majorities in voting.

2 Brian Barry, Culture and Equality (Cambridge, MA: Harvard University Press, 2001).

${ }^{3}$ It should be noted that the concept group or collective rights is used in its generic form here, acknowledging that the notion has several conceptualizations in theory and practice. In international law, it is used only in reference to the right of peoples to self-determination in Article 1 of the United Nations Charter, with peoples referring to populations of well-defined sovereign jurisdictions with boundaries, such as states or indigenous people within reserved territories. In international human rights law, it is used in reference to the right to enjoy jointly specific individual human rights that require joint exercise, such as language rights. In private law, it refers to physical entities whose membership is distinctly defined according to known criteria, including states but most often corporations and associations. In domestic public law, some states have adopted collective home-rule rights for specific cultural groups, including indigenous groups, usually inhabiting traditional home regions. In political and social science, it is used interchangeably with group rights indicating a right of specific groups to enjoy jointly certain freedoms and entitlements but without strong definition of the nature of such rights. The use in this chapters falls within the latter category.
} 
multiculturalist perspectives in political theory.${ }^{4}$ From this perspective, group or collective rights must be applied to ensure minority protections against majorities in democracies. Language use, religious practices, and symbolic matters including holidays and commemorations are areas that should be preserved via group-based, collective rights, rather than simply via individual rights. ${ }^{5}$

Some thinkers have tried to merge these views with the notions of justice for individuals in liberalism. As argued by Will Kymlicka, the full exercise of individual rights requires an acknowledgement of a status for collectives and collective rights. For Kymlicka, such thinking can be consistent with liberalism due to its enhancement of the status of minority individuals through collective rights for their identity groups. ${ }^{6}$ This perspective is called liberal pluralism (or sometimes liberal nationalism), ${ }^{7}$ and represents an attempt to combine both individualist and collective views on rights.

How might these rights questions be addressed by institutions in practice? From the liberal egalitarian view, human rights as individual rights provide sufficient remedies for those individuals who engage in practices such as the use of a minority language. International law and some domestic courts reflect this insistence on an individual basis for rights. However, collective rights approaches have also become more recognized in law and policy over time,${ }^{8}$ as with the Lund Recommendations discussed further below. Collective or group rights take a variety of forms in practice. For example, globally some countries recognize exemptions for religious group practices, such as the Canadian state's approach that the headdress of Sikh men allows them an exemption from the legal requirement of motorcycle helmets. In the United States, the use of the peyote drug, a controlled substance, is allowed for members of the Native American Church. ${ }^{9}$ Other forms of collective rights might be positive measures, such as affirmative action / positive discrimination for employment and in school admissions. ${ }^{10}$

Collective rights might also establish a foundation for minorities to govern themselves, providing a means for them to protect their identity-based practices with a minimum of majority influence. Such institutions take the form of autonomy structures for minorities. Autonomous structures have become recognized in international documents such as the Lund Recommendations as a useful means to preserve minority identity against majority

\footnotetext{
${ }^{4}$ Charles Taylor, Multiculturalism and the Politics of Recognition (Princeton: Princeton University Press, 1992); Will Kymlicka, Multicultural Citizenship (Oxford: Oxford University Press, 1995); Jacob Levy, 'Classifying Cultural Rights,' in Ethnicity and Group Rights, edited by lan Shapiro and Will Kymlicka,(New York: New York University Press, 2000).

${ }^{5}$ This dispute is not simply a theoretical one - efforts by Hungary (though unsuccessful) to get collective rights represented in the EU constitution soon after its admission to the Union demonstrate the importance of this view in Hungarian discourse. These efforts relate to the fact that ethnic Hungarians in Hungary's neighboring states comprise one of Europe's largest ethnic minorities: 'Hungary Seeks Collective Rights in European Constitution,' Radio Free Europe/Radio Liberty (RFE/RL) Newsline, 30 September 2003). Available at: http://www.minelres.Iv/mailing archive/2003-October/002968.html (accessed ???)

${ }^{6}$ Kymlicka, Multicultural Citizenship.

${ }^{7}$ Yael Tamir, Liberal Nationalism (Princeton: Princeton University Press, 1995).

${ }^{8}$ See note $X X$ above

${ }^{9}$ Levy, 'Classifying Cultural Rights.'

${ }^{10}$ Levy, 'Classifying Cultural Rights.' It should be noted that affirmative action as a positive measure to overcome discrimination is applied to the individual beneficiary and a right cast as an individual right.
} 
pressures in democracies. As the Lund Recommendations are the most widely accepted (including outside of Europe), this document will be emphasized here. ${ }^{11}$

The argument of this chapter begins from this orientation around collective remedies for minorities, in the form of autonomy as advocated by the Lund Recommendations. I first provide an overview of the territorial and non-territorial autonomy structures proposed in the Lund Recommendations, in the section below. I then outline the ways in which majorityminority disputes are framed within an institutional framework of territorial autonomy (TA), and I contrast this with the framing of majority-minority disagreements and accommodation in terms of non-territorial autonomy (NTA). I demonstrate how NTAremoves the zero-sum nature of disputes between majorities and minorities, such that better outcomes become possible for each than under conditions of TA.

\section{COLLECTIVE AND INDIVIDUAL RIGHTS, AND THE LUND RECOMMENDATIONS}

The Lund Recommendations on the Effective Participation of National Minorities in Public Life, produced by the OSCE's High Commissioner on National Minorities, outline two areas of emphasis with regard to a state's treatment of its minority. The first emphasis involves the participation of minorities in the decision-making processes of the home state, or "participation in governance of the State as a whole". ${ }^{12}$ The second emphasis is on the minority's control over matters of importance to group identity, or "self-governance over certain local and internal affairs". ${ }^{13}$

This dual desire for integration and for increased minority self-governance presents a configuration that resonates with some of the literature on ideal types of democracies more generally. As outlined by Robert Dahl in his work on democracy, favourable institutions involve two factors: inclusiveness or participation, and open contestation between different views. Inclusiveness requires broad participation in state institutions, while contestation is about the presence of different viewpoints or identities in the polity - rather than simply a homogeneous configuration of identities. ${ }^{14}$ Dahl presents a graphic depiction of how these two factors relate to each other, with favourable levels of democracy representing high levels of each factor. A similar graphic depiction was later used by Charles Tilly to present a breakdown of democratic factors into civil liberties and political rights. ${ }^{15}$

The two aspects of state interaction with minorities as endorsed by the Lund Recommendations can be represented in a similar graphic fashion. The graphic depiction inspired by Dahl allows us to logically consider how the two factors might relate to each

\footnotetext{
${ }^{11}$ High Commissioner for National Minorities (HCNM), 'The Lund Recommendations on the Effective Participation of National Minorities in Public Life \& Explanatory Note', Organization for Security and Cooperation in Europe, 1999, http://www.osce.org/hcnm/32240?download=true (accessed ??). It is worth mention that this document is wide-reaching but not legally binding. Within the context of Europe, other important documents include the Framework Convention for the Protection of National Minorities (1998) and the European Charter for Regional or Minority Languages (1998).

${ }^{12}$ Lund Recommendations, please refer to article and sub-section

${ }^{13}$ Lund Recommendations, same as note 10

${ }^{14}$ Robert Dahl, Polyarchy: Participation and Opposition (New Haven: Yale University Press, 1971), p. 7.

${ }^{15}$ Charles Tilly, Democracy (New York, Cambridge University Press, 2007), p. 47.
} 
other, when high levels of each are endorsed by the Lund Recommendations. This depiction appears in Figure 1 below.

[INSERT FIGURE 1 HERE]:

In this figure, the horizontal axis represents the aspect of the effective participation of minorities in mainstreampublic life. High levels of their participation in state affairs would be represented by points closer to the arrow. The vertical axis represents levels of minority internal self-government - or governance over their own affairs. As with the horizontal axis, high levels of self-government would be represented by points closer to the arrow of this axis. Minority participation within the main state is a function of their representation in state institutions. State recognition and representation of minorities, as well as their participation in state institutions, thus differ greatly from minority participation in their own internal self-governments. If a minority focuses efforts on its own internal self-government institutions, this focus will tend to imply a reduced focus on participation and integration in the institutions of the main state. ${ }^{16}$ These two strategies of focus thus may exist in a tradeoff relationship. ${ }^{17}$ As outlined by these premises of the Lund Recommendations, minorities should have both high levels of participation in the main state AND high levels of internal self-government. An ideal application of the Lund Recommendations would thus lie around point $\mathrm{X}$ on the above graph, where there are high levels of each factor present.

What institutions might facilitate this ideal point? A great deal of literature has considered various means to represent minorities in the decision-making processes of the state, in the form of consociationalism ${ }^{18}$ and electoral structures. ${ }^{19}$ Less consideration has been given to the aspects of autonomy that are also included in the Lund Recommendations. ${ }^{20}$ This chapter will focus on them below.

\section{STATE-MINORITY RELATIONS WITH TERRITORIAL AUTONOMY}

TA involves the allocation of governance powers to more local levels of government, on a geographic/territorial basis. The position taken by minorities toward TA will often relate to their demographic concentrations. Minorities in enclaves or regions, where they numbers might constitute a majority, tend to favour TA as a means for them to govern their own affairs within that TA territory - as is the case of the German speaking minority in Alto

\footnotetext{
${ }^{16}$ This trade-off is represented in the everyday choices made by minority members and their elites with regard to how they will spend their time, and in which institutions they will invest.

${ }^{17}$ Exceptions exist, of course, most notably the power held by Scottish MPs in Westminster allowing them to vote on matters pertaining to English constituencies. Other examples are self-rule entities, such as the Faroe Islands and Greenland, South Tyrol and the Åland Islands, all of which are represented in both legislatures and public services, and whose representatives at times have the deciding votes in matters of national interest.

${ }^{18}$ Arend Lijphart, Democracy in Plural Societies: A Comparative Exploration (New Haven: Yale University Press, 1977).

${ }^{19}$ Benjamin Reilly, Democracy in Divided Societies (New York: Cambridge University Press, 2001).

${ }^{20}$ Indeed, this relative imbalance with regard to the literature on non-territorial autonomy is one reason for this volume.
} 
Adige (South Tyrol) in Northern Italy. ${ }^{21}$ Interestingly, this goal often differs from the goals of minorities who are dispersed throughout the state, because TA for the enclave does not address the situation of those living outside of that enclave. ${ }^{22}$ For minorities who live in enclave areas, the establishment of TA for these areas can allow them to create a type of "mini-state," one that reproduces state administrative duties at a local level that is under the political control of the minority group. ${ }^{23}$

The creation of such "mini-states" via autonomous territorial structures can foster the breakup of states. As some observers have argued, territorial autonomies can provide an institutional foundation that can become a platform for those minorities that might wish to secede from the state. ${ }^{24}$ Thus, on this view the federations of Yugoslavia, Czechoslovakia and the Soviet Union met their demise when autonomous structures made efforts to exit the main states. A number of states that are experiencing increased demands for secession are seeing those claims being made from within territorial autonomies, as in the case of Quebec-Canada, Catalonia-Spain, and Scotland-UK (as well as perhaps Crimea in 2014). Territorial autonomies are intended to mitigate minority claims for secession, by allowing minorities a degree of self-governance. ${ }^{25}$ But why it is that so many do not satisfy the minorities they are intended to assist?

As envisioned by theorists, TA transfers governmental powers to minorities on a territorial basis. In doing so, it adheres to the principle of subsidiarity, which is the "notion that responsibilities should be assigned to the lowest level government that can adequately perform them". ${ }^{26}$ The Lund Recommendations also invoke subsidiarity as a reason for TA, "particularly where it would improve the opportunities of minorities to exercise authority over matters affecting them."27 TA increases the self-governance powers available to minorities, which in the Lund Recommendations document is envisioned as compatible with increasing their broader participation in the state. Both of these "prongs" are understood to support the effective engagement of minorities in the public life of the state. In theory, both of these prongs should be able to work together.

In practice, however, the "mini-states" that are created through TA tend to present a tradeoff for minorities. As has emerged in practice, minorities often tend to focus on building the

\footnotetext{
${ }^{21}$ An example of a minority, which has not had success in claiming autonomy, is the Hungarian minority living in certain counties in Romania.

22 Jóhanna Kristín Birnir, Ethnicity and Electoral Politics (New York: Cambridge University Press, 2007); Sherrill Stroschein, 'Demography in Ethnic Party Fragmentation: Hungarian Local Voting in Romania', Party Politics 17 (2011): pp. 189-204..

${ }^{23}$ This statement holds under conditions of democracy in which there are institutions governed by local elections. In some cases, local demographic realities also imply local control of the police.

${ }^{24}$ Shaheen Mozaffar and James Scarritt, 'Why Territorial Autonomy is Not a Viable Option for Managing Ethnic Conflict in African Plural Societies', Nationalism and Ethnic Politics 5 (1999): pp. 230-53; Dimitry Gorenburg, Minority Ethnic Mobilization in the Russian Federation (New York: Cambridge University Press. 2003); Henry Hale, 'Divided we Stand: Institutional Sources of Ethnofederal State Survival and Collapse', World Politics 56 (2004): pp. 165-93; Philip Roeder, Where Nation-States Come From: Institutional Change in the Age of Nationalism (Princeton: Princeton University Press, 2007).

${ }^{25}$ Donald Rothchild and Caroline Hartzell, 'Security in Deeply Divided Societies: The Role of Territorial Autonomy', Nationalism and Ethnic Politics 5 (1999): pp. 254-71.

${ }^{26}$ Ronald Watts, 'Federalism, Federal Political Systems, and Federations', Annual Review of Political Science 1 (1998): pp. 117-37, quote on p. 124.

${ }^{27}$ Lund Recommendations, article and sub-section
} 
self-government institutions of these "mini-states" at the expense of their participation in the main federal or union state - as has taken place in Quebec, Catalonia, and Scotland. ${ }^{28}$ The territorial aspect of such autonomies means that many of the aspects of state authority, such as control over the local economy, ${ }^{29}$ can be conducted by the minority groups to some degree without participation with the main state. The "mini-states" produced by TA can thus favour self-governance at the expense of minority participation in the main state.

This trade-off for the focus of minorities, between self-government and main state participation, is represented in Figure 2 below.

[INSERT FIGURE 2 HERE]:

This graph represents the fact that under circumstances of TA, the "mini-states" created by these structures in practice can draw minority attention away from participation in the main state. ${ }^{30}$ Negotiations between states and minorities are limited to discussions of the potential strength of the "mini-state" relative to state governance. These negotiations may at times be unstable. The minority will prefer point $A$, in which most governance processes are focused through self-government institutions. The state will prefer point $B$, where there could be TA but where most governance processes take place via institutions of the main state. At point $C$, states and minorities can reach a balance between their demands along these lines. However, the incentives for each to push toward their more favoured outcome

\footnotetext{
${ }^{28}$ However, see note 17.

${ }^{29}$ Local demographics also imply that a large number of those working for the local police force will be members of the ethnic group dominant in the enclave. For states that have some decentralization of the police force, there can be some local ethnic de facto control of policing as well.

${ }^{30}$ A consideration of the day-to-day allocation of time by an elite would reveal decisions to focus on one or the other institution. Further research into the time spent by elites would be useful to reveal how they think about this time allocation and institutional investment. That said, the centre-periphery power relationship require that elites of autonomous regions engage considerably with the power structures of the central state in order to keep the dialogue for peace open and to ensure the flow of subsidies.
} 
of $A$ or $B$ renders the settlement rather unstable. ${ }^{31}$ The institutions of TA establish the foundations for a "mini-state" that provides an ongoing temptation for some voices within the minority to withdraw from main state participation entirely. ${ }^{32}$ For example, Quebec has held two referenda on withdrawal; Catalonia continues to negotiate for a referendum on separation from Spain, and Scotland held such a referendum in September 2014. ${ }^{33}$ Even when unsuccessful, such referenda reinforce identity lines between the autonomous unit and the main state. In addition, TA can easily foster strong disputes between minorities and state authorities, due to the fact that the populations of those territories that are targeted for autonomy are almost never homogenous. These problems can be removed by institutions that do not produce "mini-states," but that instead produce entirely new configurations for governance: the institutions of NTA discussed in the following section.

\section{STATE-MINORITY RELATIONS AND THE PROMISE OF NON-TERRITORIAL AUTONOMY}

The potential trade-off outlined above illustrates how the "mini-state" features of TA can produce a dynamic that is difficult for states and minorities to resolve. Transforming these potential disputes to facilitate state-minority reconciliation requires a reconfiguration of available governance structures. The principle of subsidiarity has typically been taken to imply that local-level governance takes place at the level of a geographic locality. However, for matters such as language use and education for minorities, the placement of government at its closest proximity to those governed may require a non-territorial structure, based upon a personal principle.

The linguistic communities, or institutional councils that serve as the non-territorial units of the Belgian federation, provide an example of how such non-territorial structures work in practice. The Belgian federal structure that has developed since 1993 has produced a state that is quite weak at the centre. Much of the work of governance takes place within the six units of the Belgian federation. There are three territorial units: Flanders, Wallonia, and Brussels capital. There are also three non-territorial units, or the linguistic communities: the Francophone, Flemish community, and the Germans. The territorial units tend to focus on functions linked to territory, such as economic policy and infrastructure matters such as transport. The non-territorial units control matters similar to those outlined in the Lund Recommendations for non-territorial units: education, language, and culture - as well as health care, the latter which has a strong linguistic element. To further complicate matters, the Flemish territorial and non-territorial units are fused. ${ }^{34}$ The primary result of this structure is a reduction of potential disputes over linguistic matters in the Brussels capital region, which is home to both Francophone and Flemish speakers. Instead, linguistic

\footnotetext{
${ }^{31}$ In practice, most TA negotiations take place through specifically designed institutions allowing for addressing issues in an orderly manner and according to legal provisions. If these institutions are well-designed, the settlement is likely to be stable and may even allow for productive co-operation.

32 The potential likelihood for some of these voices to succeed in making a case for withdrawal will vary across different contexts and will also depend on the particular structures of the territorial autonomies in question. The degree of power devolution may determine whether mobilization occurs.

${ }^{33}$ Examples from Eastern Europe include Gagauzia in Moldova and Crimea in Ukraine before Russian annexation.

${ }^{34}$ Dirk Jacobs and Marc Swyngedouw, 'Territorial and Non-territorial Federalism in Belgium: Reform of the Brussels Capital Region, 2001', Regional and Federal Studies 13 (2003): pp. 127-39.
} 
matters that could easily become group disputes in Brussels are removed from the arena of inter-group debates and placed within each linguistic community. ${ }^{35}$ The Belgian structures thus include aspects of representation and governance. ${ }^{36}$ As such, they could provide a model for states that face complex governance problems, such as Bosnia, Kosovo, or Ukraine ${ }^{37}$ especially in places in which one ethnic group refuses to be governed by another. The presence of NTA allows for debates to be concentrated within those groups affected, rather than requiring debates over identity issues to take place between groups.

NTA thus allocates certain functions of governance according to a personal principle, rather than a territorial principle. The notion that groups need not all be subject to the same rule is an old concept originating in the millet system of the Ottoman Empire. In this system, the Muslim Empire allowed non-Muslims to have some control over their own affairs, delegating powers to Jewish and Christian religious leaders to adjudicate over areas such as family law. Individuals of one of these groups could access the rules of their own community even if they were scattered throughout a particular territory - because these rules adhered to individuals on a personal, rather than a territorial, principle. ${ }^{38}$ This notion that identity issues might be governed according to a personal principle was also taken up by Otto Bauer and Karl Renner as the Austro-Hungarian Empire began to unravel in the late 1800s, due to similar problems of minority governance. ${ }^{39}$ Although these ideas were not put into practice in Austro-Hungary, they continue to provide a foundation for potential governance options that might eschew direct conflicts between ethnic groups over identity issues and governance. $^{40}$

The non-territorial linguistic communities in Belgium provide and administer education to those French and Flemish families who may not live in geographical proximity to others who speak their language. Their children can attend schools in their own language without being forced to move to other geographic locations, at least where such schools are provided. ${ }^{41}$ As noted by the Lund Recommendations, non-territorial arrangements might provide

\footnotetext{
${ }^{35}$ Philippe Van Parijs, 'Power Sharing versus Border-Crossing in Ethnically Divided Societies', in Designing Democratic Institutions, edited by lan Shapiro and Steven Macedo (New York: New York University Press, 2000), pp. 296-320.

${ }^{36}$ An overview of these structures and their specific powers appears in Jacobs and Swyngedouw 2003.

37 Sherrill Stroschein, 'What Belgium Can Teach Bosnia: The Uses of Autonomy in 'Divided House' States', Journal on Ethnopolitics and Minority Issues in Europe (JEMIE), 3 (2003): available online at: http://www.ecmi.de/jemie/ (accessed ??); and Stroschein, 'Making or Breaking Kosovo: Applications of Dispersed State Control', Perspectives on Politics 6 (2003): pp. 655-74. It should be noted that with the 2008 Constitution, Kosovo has begun the path towards a dual lingual state. Ukraine, on the other hand, is in a state of flux, and the language communities are far less distinct and there difficult to identify.

${ }^{38}$ Uri Ra'anan, 'The Nation-State Fallacy', in Conflict and Peacemaking in Multiethnic Societies, edited by Joseph Montville (New York: Lexington Books / Macmillan, 1991), pp. 12-15, and Ephraim Nimni, 'Introduction: The National Cultural Autonomy Model Revisited', in National Cultural Autonomy and Its Contemporary Critics, edited by Ephriam Nimni (New York: Routledge, 2005).

${ }^{39}$ Karl Renner, 'State and Nation,' in National Cultural Autonomy and Its Contemporary Critics, edited by Nimni. The original was written in 1899 and is reproduced in the book.

${ }^{40}$ For more on the historical trajectory of this concept within a particular context, see Alexander Osipov, "Nonterritorial Autonomy in the Post-Soviet Space: From Framing to Action and Back," in this volume.

${ }^{41}$ The degree of NTA is here not easy to determine given that the education to these pupils is provided as entitlements within the Belgian system of education as opposed to self-governing school boards.
} 
remedies in instances in which "a group is geographically dispersed" ${ }^{42}$ From a justice perspective, a group member living outside of an enclave should have the same rights as one living within a group enclave. Non-territorial structures enable this possibility, and do so in a way that reduces potential tense exchanges between groups over the matter of language education for children. Rather than requiring homogenous populations for the purpose of education provision, these structures redefine the means of provision instead potentially transforming the zero-sum nature of potential disputes between groups. As outlined in more general terms in the Lund Recommendations, non-territorial arrangements may perform "functions," which need not be linked to territory: "education, culture, use of minority language, religion, and other matters crucial to the identity and way of life of national minorities". ${ }^{43}$ In practice, most examples of non-territorial units generally seem to limit themselves to these applications, though health care can be considered a linguistic matter for many individuals.

In removing the territorial and demographic aspects of these linguistic, religious, or cultural practices, NTA allows for a potential transformation of the negotiations between states and minorities. TA focuses minority attention on self-government and the strengthening of "mini-states," as outlined above, whereas NTA allows for minorities to engage in selfgovernance on these matters of identity, while leaving non-identity matters within the structure of the main state. Governance functions requiring a territorial focus, such as commerce, agriculture, and transport, could be addressed within the main state structure, while non-territorial units would allow for their self-governance on identity matters. In contrast, the structure of TA does not distinguish between issue functions, and requires all matters to lie within the administration of the "mini-state" unit, with the exception of security and foreign policy matters. TA produces a trade-off that NTA eliminates. NTA is thus a useful policy option for places with complex governance problems.

This reconfiguration of state-minority disputes under NTA produces an outcome displayed in Figure 3 below.

[INSERT FIGURE 3 HERE]:

\footnotetext{
42 Lund Recommendations, article and sub-section

${ }^{43}$ Lund Recommendations, article and sub-section
} 
This graph illustrates how conditions of self-governance and state participation for minorities can remove the territorial constraints illustrated in Figure 2. Without the tradeoff between self-government and state participation that is posed for minorities under TA, higher points can be reached on each factor. Negotiations between states and minorities are not forced into the zero-sum constraints of TA. By breaking down the notion of governance into specific functional competences, it is possible to reframe these potential disputes for better outcomes for each.

These functional competences might be either formal or informal in practice. ${ }^{44}$ Formal competences might be represented in a constitution or in formal procedures, as is the case with Hungary's minority governments and in Belgium's non-territorial federative units. Informal competences might take several forms, including societal organizations or NGOs, such as the organizations that exist on the German-Danish border to provide resources for the members of each community. In addition, informal non-territorial practices and procedures might develop in a state vacuum, as was perhaps the case with Kosovo's pre1999 shadow government. The discussions in this book provide examples from both formal and informal contexts. They share a focus on a personal, rather than a territorial, principle for allocating governance functions.

\section{CONCLUSIONS}

In this chapter, I have provided an outline of the way in which NTA can evade some of the problems of TA by reconfiguring disputes between states and minorities. In removing the "mini-state" nature of governance structures for minorities, non-territorial solutions facilitate minority strength in both areas of self-governance and in broader state participation. NTA emphasises governance as a menu of functional competences. Territorial functions such as the regulation of commerce and transport can remain within the realm of the main state, while non-territorial functions such as linguistic matters and education can be allocated to the minority without the creation of "mini-states".

NTA is grounded on a personal principal for governance, and is thus similar to the personal principle that lies behind the application of rights and rules in legal pluralism. The fact of the existence of different group identities within the legal systems of diverse states has prompted more conversation about the way in which the individual members of different groups might access different legal rights within the state. ${ }^{45}$ Like NTA, the differential application of laws might also provide a means to address potential governance disputes between groups, because laws can be applied on a personal, rather than a territorial, principle. The potential avoidance of territorial restrictions shows great promise for transforming negotiations between states and minorities by eliminating trade-offs on

\footnotetext{
${ }^{44}$ Gretchen Helmke and Steve Levitsky, 'Informal Institutions and Comparative Politics: A Research Agenda', Perspectives on Politics 2 (2004): pp. 725-40.

45 Levy, 'Classifying Cultural Rights.'
} 
identity questions. The chapters in this book provide examples of how some of these current arrangements work in practice.

\section{References}

Barry, Brian, Culture and Equality, (Cambridge, MA: Harvard University Press, 2001).

Birnir, Jóhanna Kristín, Ethnicity and Electoral Politics, (New York: Cambridge University Press, 2007).

Dahl, Robert, Polyarchy: Participation and Opposition, (New Haven: Yale University Press, 1971).

Deets, Stephen, and Sherrill Stroschein, 'Dilemmas of Autonomy and Liberal Pluralism: Examples Involving Hungarians in Central Europe'. Nations and Nationalism, 11, no. 2 (2005): 285-305.

Gorenburg, Dimitry, Minority Ethnic Mobilization in the Russian Federation, (New York: Cambridge University Press, 2003).

Hale, Henry, 'Divided we Stand: Institutional Sources of Ethnofederal State Survival and Collapse'. World Politics 56, no. 2 (2004): 165-93.

Helmke, Gretchen, and Steve Levitsky, 'Informal Institutions and Comparative Politics: A Research Agenda'. Perspectives on Politics 2, no. 4 (2004): 725-40.

High Commissioner for National Minorities (HCNM), 'The Lund Recommendations on the Effective Participation of National Minorities in Public Life \& Explanatory Note', Organization for Security and Cooperation in Europe (1999). Available online at:

http://www.osce.org/hcnm/32240?download=true (accessed ??). Jacobs, Dirk, and Marc Swyngedouw, 'Territorial and Non-territorial Federalism in Belgium: Reform of the Brussels Capital Region, 2001'. Regional and Federal Studies 13, no. 2 (2003): 127-39.

Kymlicka, Will, Multicultural Citizenship, (Oxford: Oxford University Press, 1995).

Levy, Jacob, 'Classifying Cultural Rights'In Ethnicity and Group Rights, edited by lan Shapiro and Will Kymlicka (New York: New York University Press, 2000).

Lijphart, Arend, Democracy in Plural Societies: A Comparative Exploration (New Haven: Yale University Press, 1977).

Mozaffar, Shaheen, and James Scarritt, 'Why Territorial Autonomy is Not a Viable Option for Managing Ethnic Conflict in African Plural Societies'. Nationalism and Ethnic Politics 5, nos. 3-4 (1999): 230-53.

Nimni, Ephraim. 'Introduction: The National Cultural Autonomy Model Revisited'. In National Cultural Autonomy and Its Contemporary Critics, edited by Ephriam Nimni (New York: Routledge, 2005). 
Ra'anan, Uri, 'The Nation-State Fallacy'. In Conflict and Peacemaking in Multiethnic Societies, edited by Joseph Montville (New York: Lexington Books / Macmillan, 1991).

Radio Free Europe/Radio Liberty (RFE/RL), 'Hungary Seeks Collective Rights in European Constitution,' RFE/RL Newsline, 30 September 2003. Available at:

http://www.minelres.lv/mailing archive/2003-October/002968.html (accessed ??)

Reilly, Benjamin, Democracy in Divided Societies, (New York: Cambridge University Press, 2001).

Renner, Karl, 'State and Nation'. In National Cultural Autonomy and Its Contemporary Critics, edited by Ephraim Nimni (New York: Routledge, 2005).Roeder, Philip, Where Nation-States Come From: Institutional Change in the Age of Nationalism, (Princeton: Princeton University Press, 2007).

Rothchild, Donald, and Caroline Hartzell, 'Security in Deeply Divided Societies: The Role of Territorial Autonomy'. Nationalism and Ethnic Politics 5, nos. 3-4 (1999): 254-71.

Stroschein, Sherrill, 'What Belgium Can Teach Bosnia: The Uses of Autonomy in 'Divided House' States'. Journal on Ethnopolitics and Minority Issues in Europe (JEMIE), 3 (2003). Available at: http://www.ecmi.de/jemie/ (accessed ??).

---, 'Making or Breaking Kosovo: Applications of Dispersed State Control'. Perspectives on Politics 6, no. 4 (2008): 655-74.

---, 'Demography in Ethnic Party Fragmentation: Hungarian Local Voting in Romania'. Party Politics 17, no. 2 (2011): 189-204.

Tamir, Yael, Liberal Nationalism, (Princeton: Princeton University Press, 1995).

Taylor, Charles, Multiculturalism and the Politics of Recognition, (Princeton: Princeton University Press, 1992).

Tilly, Charles, Democracy, (New York: Cambridge University Press, 2007).

Van Parijs, Philippe, 'Power Sharing versus Border-Crossing in Ethnically Divided Societies'. In Designing Democratic Institutions, edited by lan Shapiro and Steven Macedo (New York: New York University Press, 2000).

Waters, Timothy, and Rachel Guglielmo, 'Two Souls to Struggle With'. In State and Nation Building in East Central Europe, edited by John Micgiel (New York: Columbia University, Institute on East Central Europe, 1996).

Watts, Ronald, 'Federalism, Federal Political Systems, and Federations'. Annual Review of Political Science 1: (1998) 117-37. 
FIGURE 1:

Self-

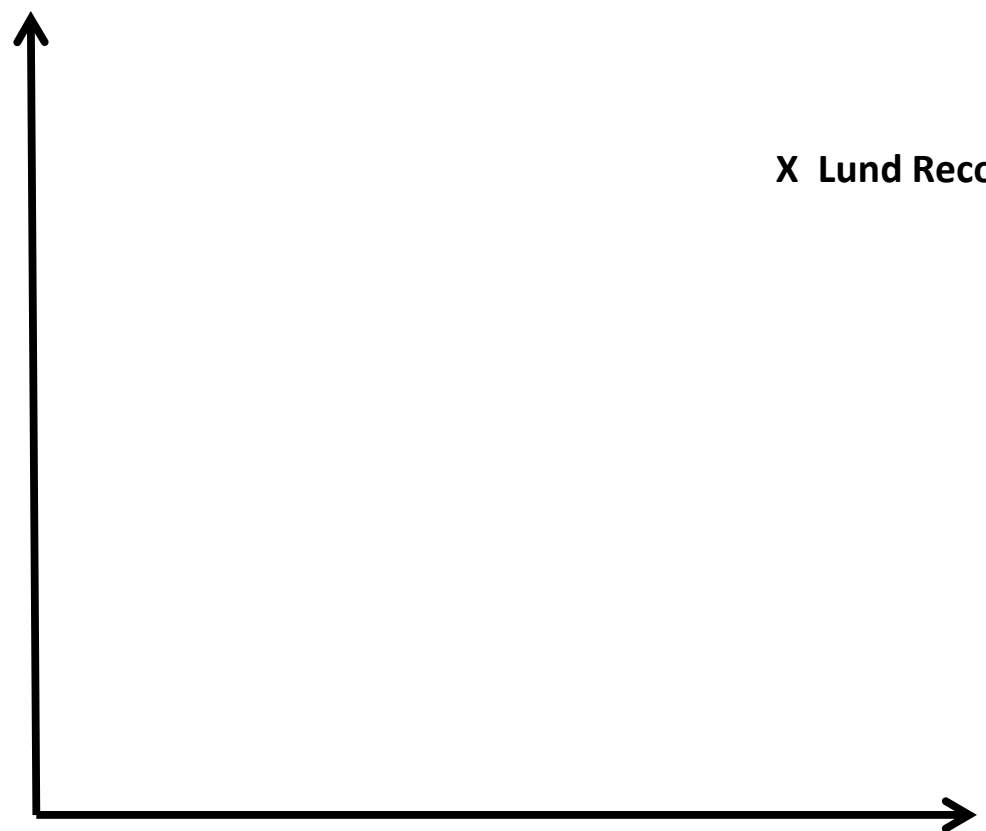

State Participation

Figure 1. Aspects of the Lund Recommendations: self-government and state participation for minorities - higher levels of each represented by proximity to arrows on each line. 


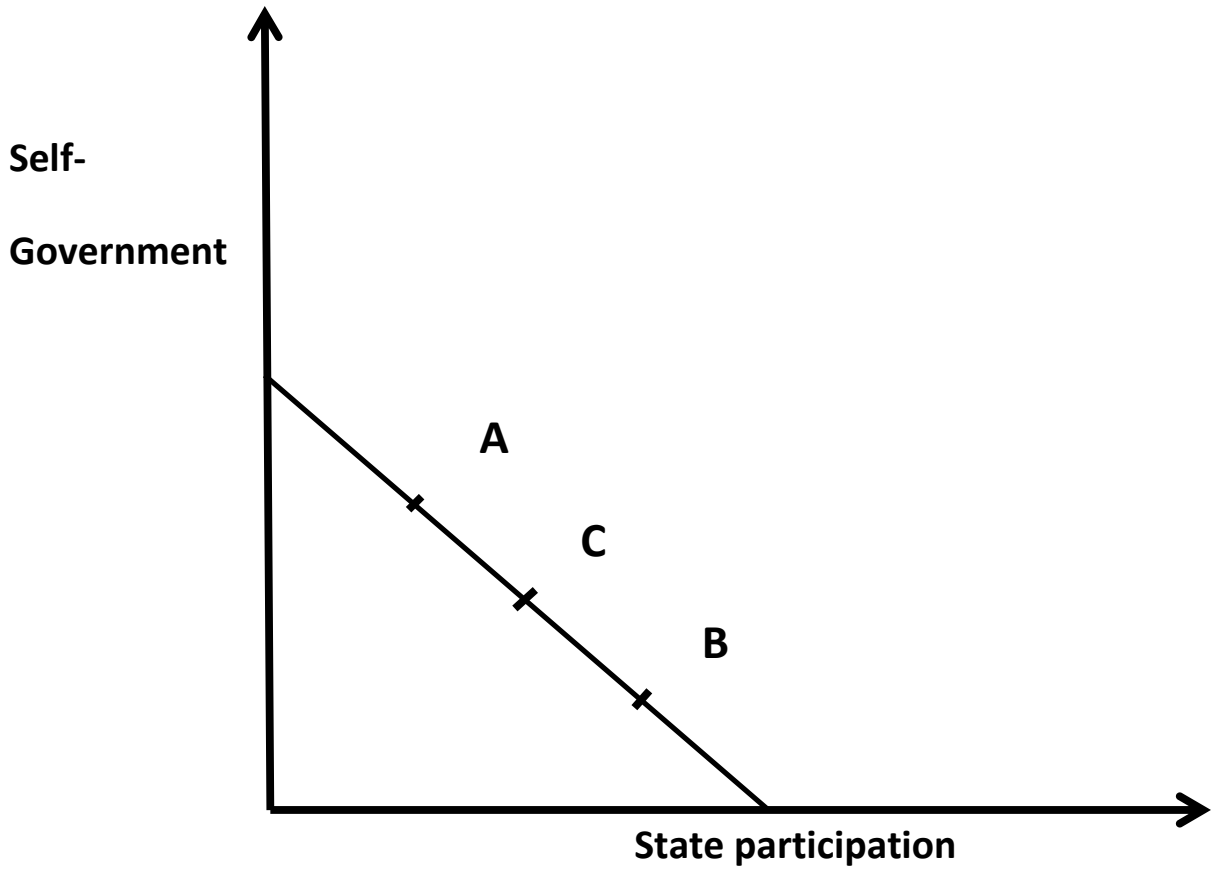

Figure 2. Minorities, TA and the Lund factors. Territorial structure presents a trade-off structure that limits options for minority governance to the line. Negotiations between states and minorities are limited to points along these lines such as A, B, and C. However, full potential is not reached. 
FIGURE 3:

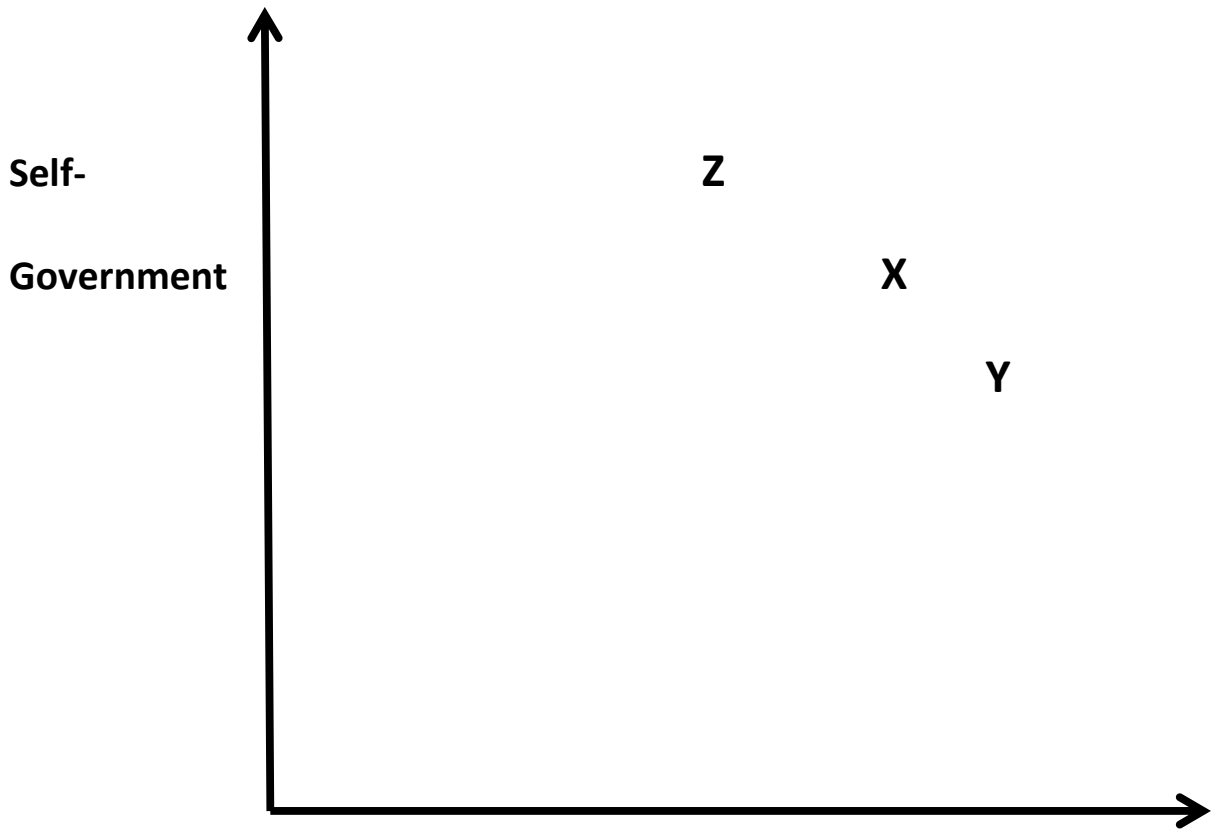

State Participation

Figure 3. Minorities, NTA and the Lund factors. Non-territorial aspects remove the tradeoff effects of territoriality with regard to minority questions. Negotiations between states and minorities can result in points $\mathrm{X}, \mathrm{Y}$, or $\mathrm{Z}$, maximizing potential. 